\title{
Analisis Manajemen dan Iklim Keselamatan di Lingkungan Kerja pada Industri Semen Indonesia: Sebuah Review
}

\author{
Management Analysis and Safety Climate in the Work Environment in the \\ Indonesian Cement Industry: A Review
}

\author{
Intania Dwi Ningtias ${ }^{1}$, Taufiq Ihsan $^{2}$, Resti Ayu Lestari ${ }^{3}$ \\ ${ }^{1}$ Jurusan Teknik Lingkungan Fakultas Teknik Universitas Andalas, Sumatera \\ Barat, Indonesia \\ *Korespondensi penulis: intaniadwiningtias@gmail.com
}

Penyerahan: 17-02-2019, Perbaikan: 22-03-2020, Diterima: 26-04-2020

\begin{abstract}
Work safety climate analysis in the cement industry in Indonesia was carried out by knowing the workers' perceptions of the existing Occupational Safety and Health (OSH) policy. Every work process in the cement industry, starting from the mining process to the packaging process, has a potential K3 hazard because it involves various kinds of equipment, electrical equipment, and the interaction of workers with equipment. So that the production process runs smoothly, you should minimize the occurrence of work errors. Based on a literature review, with a sample population ranging from 30 to 102 sample workers, there were some of the most influential factors in management and work safety climate in the cement industry, age, years of service, attitudes and perceptions of the application of $\mathrm{OSH}$, knowledge (OSH), safety talk, transformational leadership style, organizational culture, extrinsic motivation, physical work environment in the workplace and $\mathrm{OSH}$ policies in the company. Suggested improvements were worker characteristics, safety behavior and safety culture.
\end{abstract}

Keywords: Safety climate, Cement industry, Indonesia, OSH.

\begin{abstract}
ABSTRAK
Analisis iklim keselamatan kerja pada industri semen di Indonesia dilakukan dengan mengetahui persepsi para pekerja terhadap kebijakan Keselamatan dan Kesehatan Kerja(K3) yang ada. Setiap proses kerja yang terdapat di industri semen mulai dari proses penambangan hingga proses pengemasan mempunyai potensi bahaya K3 karena melibatkan berbagai macam peralatan, alat-alat listrik, dan interaksi pekerja dengan peralatan. Agar proses produksi berjalan lancar, sebaiknya meminimalisir terjadinya kesalahan kerja. Berdasarkan kajian literatur, dengan populasi sampel berkisar antara 30 hingga 102 pekerja sampel, terdapat beberapa faktor yang paling berpengaruh dalam manajemen dan iklim keselamatan kerja di Industri semen yaitu umur, masa kerja, sikap dan persepsi terhadap penerapan K3, pengetahuan (K3), safety talk, gaya kepemimpinan transformasional, budaya organisasi, motivasi ekstrinsik, lingkungan kerja fisik di tempat kerja dan kebijakan K3 pada perusahaan. Perbaikan yang disarankan meliputi karakteristik pekerja, safety behavior dan budaya keselamatan.
\end{abstract}

Kata kunci: Iklim keselamatan, Industri semen, Indonesia, K3. 


\section{PENDAHULUAN}

Keselamatan dan kesehatan kerja (K3) merupakan bagian penting dalam industrialisasi, dikarenakan efisiensi produksi semakin diperhatikan seiring dengan meningkatnya risiko kecelakaan dan penyakit akibat kerja. Hal ini bertujuan untuk mengurangi kecelakaan kerja dan meningkatkan produktivitas kerja (Sucipto, 2014). Menurut International Labour Organization (ILO, 2018) terdapat lebih dari 2,78 juta kematian per tahun karena kecelakaan kerja atau penyakit terkait pekerjaan (ILO, 2018). Menurut BPJS Ketenagakerjaan Indonesia tercatat kecelakaan kerja sepanjang tahun 2019 berjumlah 77.295 kasus kecelakaan kerja (BPJS Ketenagakerjaan, 2019). Upaya yang dapat dilakukan untuk mengatasi kecelakaan di tempat kerja yaitu dengan melakukan pendekatan keselamatan kerja. Pendekatan keselamatan kerja dapat dilakukan melalui pelaksanaan sistem manajemen keselamatan yang efektif. Metode pendekatan keselamatan yang banyak digunakan dan fokus terhadap faktor manusia yaitu melalui iklim keselamatan. Iklim keselamatan kerja dapat mempengaruhi perilaku dan keterlibatan pekerja dalam praktik keselamatan (Ferret, 2002).

Zohar (1980) mendefinisikan iklim keselamatan merupakan sebuah persepsi karyawan terhadap kebijakan keselamatan, prosedur, praktik, serta seluruh kepentingan dan prioritas keselamatan kerja (Guldenmund, 2010). Iklim keselamatan pada pekerja dapat dipengaruhi oleh beberapa karakteristik responden diantaranya usia, jenis kelamin, masa kerja, posisi jabatan dan tingkat pendidikan. karakteristik responden tersebut dapat mempengaruhi iklim keselamatan yang kemudian mempengaruhi perilaku keselamatan individu (Choudhry dkk., 2009). Beberapa penelitian menunjukkan adanya perbedaan iklim keselamatan pekerja berdasarkan usia, masa kerja, posisi jabatan dan tingkat pendidikan (Choudhry dkk., 2009; Vinodkumar dan Bhasi, 2009; Siu dkk., 2003; Bergh, 2011; Ameko, 2015). Iklim keselamatan dibangun oleh berbagai faktor/dimensi yang mendukung terciptanya iklim yang aman. Berbagai peneliti telah mencoba mengidentifikasi dimensidimensi tersebut. Flin dkk., (2000), mengemukakan bahwa dimensi iklim keselamatan sangat bervariasi sesuai dengan perbedaan dalam industri, perusahaan dan praktik kerja (Flin, dkk., 2000). Dalam beberapa penelitian iklim keselamatan ditemukan dimensi umum yang sering muncul yaitu komitmen manajemen terhadap keselamatan (Neal, dkk., 2000). Berdasarkan teori dan hasil empiris Kines, dkk., (2011) menyimpulkan bahwa instrumen yang mengukur iklim keselamatan harus mencakup semua persepsi yang mempengaruhi motivasi individu, serta kondisi yang berpengaruh terhadap aspek relasional keselamatan kerja.

Iklim keselamatan kerja pada industri semen perlu dianalisis untuk mengetahui persepsi para pekerja terhadap kebijakan K3 yang ada pada industri. Industri semen diketahui memiliki kegiatan produksi meliputi beberapa proses yaitu raw mill, kiln mill (proses pembakaran menggunakan preheater, sehingga membentuk kristal klinker yang kemudian didinginkan di cooler), dan cement mill (proses penggilingan dalam tabung yang berputar, yang berisi bola-bola baja sehingga berbentuk serbuk semen yang halus). Setiap proses kerja yang terdapat di industri semen mulai dari 
proses penambangan hingga proses pengemasan mempunyai potensi bahaya keselamatan dan kesehatan kerja karena melibatkan berbagai macam peralatan, alat-alat listrik, dan interaksi pekerja dengan peralatan. Agar proses produksi berjalan lancar, sebaiknya meminimalisir terjadinya kesalahan kerja dan mengurangi dampak penyebab kecelakaan kerja sehingga kualitas produksi semen dan produktivitas pekerja optimal.

Berdasarkan uraian di atas maka dilakukan penelitian tentang kajian manajemen dan iklim keselamatan di lingkungan kerja pada industri semen. Tujuannya adalah untuk menganalisis manajemen dan iklim keselamatan di lingkungan kerja di industri semen, menganalisis pengaruh kelompok karakteristik responden (umur, masa kerja, tingkat pendidikan, jabatan dan bagian kerja) dan merumuskan solusi perbaikan manajemen dan di lingkungan kerja di industri semen.

\section{METODE}

Teknik pengumpulan data yang digunakan dalam penelitian ini adalah library research atau studi literatur. Setelah dilakukan penyaringan judul, abstrak dan bereputasi nasional atau international, literatur utama yang didapatkan sebanyak 10 buah literatur terkait penelitian manajemen dan iklim keselamatan di lingkungan kerja pada industri semen di Indonesia. Ukuran sampel pada beberapa literatur berkisar antara 30 hingga 102 buah sampel.

Tahapan penelitian ini meliputi studi literatur, pengumpulan data, serta pengolahan data dan kajian ilmiah. Hal-hal yang dibahas adalah statistik deskriptif responden, dimensidimensi iklim keselamatan kerja serta interpretasi dari nilai-nilai tersebut, perbedaan berdasarkan kelompok karakteristik responden yaitu berdasarkan kelompok umur, jenis kelamin masa kerja, pendidikan terakhir, jabatan, dan bagian kerja, statistik gambaran iklim keselamatan kerja pada industri semen. Hasil analisis beberapa literatur, selanjutnya dilakukan identifikasi faktor manajemen dan iklim keselamatan kerja dan mengevaluasi sejauh mana pengaruhnya terhadap manajemen dan iklim keselamatan kerja serta memberikan solusi perbaikan berdasarkan literatur atau peraturan perundang-undangan.

\section{HASIL}

\section{Karakteristik Literatur}

Ukuran sampel pada beberapa literatur berkisar antara 30 hingga 102 buah sampel, dengan 2 literatur melaporkan ukuran sampel 60 buah sampel. Kajian literatur dilakukan di berbagai industri semen di Indonesia, yaitu di PT. Semen Tonasa (2 literatur), PT. Semen Indonesia (1 literatur), PT. Semen Bosowa Maros ( 2 literatur), PT. Semen Kupang (1 literatur), PT. Holcim Indonesia (1 literatur ), PT. Semen Padang (1 literatur), PT. Semen Baturaja (1 literatur). Sembilan literatur menggunakan desain observational, kuesioner, dan wawancara. Metode analisis yang digunakan pada literatur ini yaitu 6 literatur menggunakan metode analisis uji chi square, 2 literatur menggunakan metode analisis uji phi, 3 literatur menggunakan metode uji partial (Uji t), 3 literatur menggunakan metode uji simultan (Uji F), 1 literatur menggunakan uji regresi logistik dan 2 literatur menggunakan uji fisher's excat.

\section{Karakteristik Responden}

Dari 10 literatur yang dinilai, hasil uji statistik yang diperoleh pada penelitian Almani, dkk (2014) yaitu 
dengan nilai $p=0,002$ dan hasil uji phi menunjukkan nilai $\varphi=-0,44$. Ini berarti terdapat hubungan antara umur dengan perilaku tidak aman karyawan di tempat kerja PT. Semen Tonasa yang memiliki derajat kekuatan hubungan sedang dan pada penelitian Shiddiq, dkk (2014) berdasarkan hasil uji chi square dan uji phi, diperoleh nilai $p=0,016$ dan $\varphi=0,329$. Ini menunjukkan bahwa ada hubungan antara faktor umur dengan persepsi karyawan terhadap penerapan SMK3 di PT. Semen Tonasa. Hal ini berbeda dengan penelitian Isa, dkk (2018), dimana berdasarkan hasil analisis dengan uji regresi logistik didapatkan nilai $\mathrm{p}=$ $0,641(p<0,25)$ yang berarti umur tidak memiliki pengaruh yang signifikan dengan perilaku keselamatan. Rentang usia pekerja pada penelitian ini 23-47 tahun. Pekerja yang berusia $\geq 28$ tahun sebanyak $50,0 \%$ dan memiliki perilaku keselamatan yang kurang.

Berdasarkan hasil uji statistik yang diperoleh pada penelitian Almani,dkk (2014) didapatkan dengan nilai $p=0,008$ dan $\varphi=0,374$ dan pada penelitian Shiddiq, dkk (2014) nilai $\mathrm{p}=0,026$ dan hasil uji phi menunjukkan nilai $\varphi=0,304$. Berdasarkan hasil uji statistik diperoleh kedua literatur menunjukkan bahwa ada hubungan antara masa kerja dengan persepsi karyawan dan perilaku tidak aman karyawan terhadap penerapan SMK3 di tempat kerja PT. Semen Tonasa dengan derajat kekuatan hubungan sedang. Hal ini berbeda dengan penelitian Isa,dkk (2018), didapatkan dari hasil uji statistik regresi logistik $(p<0,25)$ yaitu pada 2 tahun masa kerja $(p=0,937), 3$ tahun masa kerja $(p=0,999)$ dan 4 tahun masa kerja $(p=0,718)$ dapat disimpulkan bahwa masa kerja tidak memiliki pengaruh signifikan terhadap perilaku keselamatan kerja.
Pada penelitian Almani, dkk (2014) hasil uji statistik menggunakan fisher's exact test antara tingkat pendidikan dengan persepsi penerapan SMK3 diperoleh nilai $p=1,00>0,05$. Nilai tersebut menunjukkan bahwa tidak ada hubungan antara tingkat pendidikan dengan persepsi karyawan unit terhadap penerapan SMK3 di PT. Semen Tonasa. Tingkat pendidikan dengan kategori pendidikan tinggi (SMA-Akademi /PT), yaitu sebanyak 58 orang $(96,7 \%)$, sedangkan untuk kategori rendah (tidak sekolah-SMP), yaitu sebanyak 2 orang $(3,3 \%)$.

\section{Safety Behavior}

Dari 10 literatur terdapat 5 literatur yang berhubungan dengan pengetahuan terhadap penerapan SMK3. Pada penelitian Almani, dkk (2014) hasil uji statistik menggunakan fisher's exact test diperoleh nilai $p=0,002$ dan $\varphi=$ 0,425 dan pada penelitian Shiddiq, dkk (2014) diperoleh nilai $p=0,036$ dan $\varphi=0,290$. Nilai tersebut menunjukkan bahwa ada hubungan antara pengetahuan dengan persepsi dan perilaku tidak aman karyawan dalam penerapan SMK3 di tempat kerja PT. Semen Tonasa. Pada penelitian Basri dan Ibrahim (2018), hubungan antara pengetahuan rambu-rambu keselamatan (safety sign) dengan pencapaian target pengisian semen pada bagian packer menggunakan uji statistik fisher's exact test diperoleh nilai $p=0,65>0,05$. Hal ini menunjukkan bahwa tidak terdapat hubungan antara pengetahuan rambu-rambu keselamatan (safety sign) dengan pencapain target pengisian semen pada bagian packer pada PT. Semen Bosowa Maros

Pada penelitian Basri dan Ibrahim (2018) hubungan antara penggunaan Alat Pelindung Diri (APD) dengan pencapaian target pengisian semen 
pada bagian packer, didapatkan nilai $p=0,048<0,05$ yang mana menunjukkan bahwa terdapat hubungan antara penggunaan alat pelindung diri (APD) dengan pencapaian target pengisian semen pada bagian packer di PT Semen Bosowa Maros. Hal ini juga sesuai pada penelitian Raodhah dan Gemely (2014) yaitu hubungan antara pengetahuan $\mathrm{K} 3$ dengan penggunaan Alat Pelindung Diri (APD) pada pekerja bagian packer di PT Semen Bosowa Maros. Hasil uji statistik menggunakan uji chi square diperoleh nilai $p=0,00<0,05$. Hal ini menunjukkan bahwa terdapat hubungan antara pengetahuan $\mathrm{K} 3$ terhadap penggunaan APD bagian packer pada PT Semen Bosowa Maros. Kemudian pada penelitian Raodhah dan Gemely (2014) faktor ketersediaan APD dengan analisis chi square diperoleh nilai $p=0,241$ $(p>0,05)$ yang berarti tidak ada hubungan antara ketersediaan APD dengan penggunaan APD pada karyawan bagian packer.

Pada penelitian Almani, dkk (2014) hasil uji statistik menggunakan fisher's exact test diperoleh nilai $p=0,008$. Nilai tersebut menunjukkan bahwa ada hubungan antara pelatihan K3 dengan persepsi penerapan SMK3 di PT. Semen Tonasa. Hal ini juga sama dengan penelitian Raodhah dan Gemely (2014) didapatkan hasil dengan uji statistik chi-square dengan nilai $p=$ $0.00 \quad(p<0,05)$ yang menunjukan terdapat hubungan antara pelatihan K3 dengan penggunaan APD pada karyawan bagian packer di PT Semen Bosowa Maros. Namun hal ini berbeda dengan penelitian Shiddiq, dkk (2014) dan Basri dan Ibrahim (2018). Pada penelitian Shiddiq, dkk (2014) diperoleh nilai $p=0,568$ dan $\varphi=0,371$ dimana tidak adanya hubungan pelatihan K3 terhadap perilaku tidak aman karyawan di bagian produksi unit IV PT. Semen Tonasa. Pada penelitian Basri dan Ibrahim (2018) hasil uji statistik chisquare diperoleh nilai $p=0.369>0,05$ yang menunjukkan bahwa tidak terdapat juga hubungan antara frekuensi pelatihan $\mathrm{K} 3$ dengan pencapaian target pengisian semen dibagian packer di PT Semen Bosowa Maros.

Pada penelitian Shiddiq, dkk (2014) hasil uji statistik antara sikap dan persepsi dengan perilaku tidak aman dalam penerapan SMK3 diperoleh nilai $p=0,011$ dan $\varphi=0,359$. Nilai tersebut menunjukkan bahwa ada hubungan antara persepsi K3 dengan perilaku tidak aman karyawan dengan derajat kekuatan hubungan sedang.

Pada penelitian Gumelar dan Ardyanto (2018) hasil tingkat kepatuhan dan pengetahuan tentang APD dilakukan dengan uji statistik menggunakan pearson chi-square diperoleh nilai $p=0,001 \quad(p<0,05)$. Hal ini menunjukan bahwa terdapat hubungan antara safety talk dengan kepatuhan menggunakan APD. Selanjutnya dihubungkan antara safety talk dengan tingkat pengetahuan tentang APD pekerja. Lalu dilakukan uji statistik menggunakan uji analisis statistik pearson chi-square dan diperoleh hasil $p=0,000 \quad(p<0,05)$. Hal ini juga menunjukan bahwa terdapat hubungan antara safety talk dengan tingkat pengetahuan tentang APD.

\section{Budaya Keselamatan}

Pada penelitian Sugiono dan Rachmawati (2019) hasil uji statistik dengan uji $F$ menghasilkan nilai signifikansi sebesar 0,000 <0,05 sehingga faktor gaya kepemimpinan transformasional secara simultan berpengaruh signifikan terhadap kinerja karyawan.

Pada penelitian Sugiono dan Rachmawati (2019) hasil uji statistik 
dengan uji $F$ menghasilkan nilai signifikansi sebesar 0,009<0,05 sehingga faktor budaya organisasi berpengaruh signifikan terhadap kinerja karyawan. Hal ini juga sama dengan penelitian Pramudianto (2019). Hasil uji statistik dengan uji $\mathrm{T}$ menghasilkan nilai signifikansi sebesar $0,000<0,05$. Sehingga memiliki nilai positif yang berarti bahwa telah terjadi sebuah hubungan antara budaya organisasi dengan kinerja karyawan.

Pada penelitian Sugiono dan Rachmawati (2019) hasil uji statistik dengan uji $F$ menghasilkan nilai signifikansi sebesar 0,019<0,05, sehingga faktor motivasi ekstrinsik berpengaruh signifikan terhadap kinerja karyawan.

Pada penelitian Pramudianto (2019) hasil uji statistik dengan uji $T$ menghasilkan nilai signifikansi sebesar $0,000<0,05$. Sehingga memiliki nilai positif yang berarti bahwa lingkungan kerja fisik memiliki hubungan yang positif terhadap kinerja karyawan. Hal ini juga sama dengan penelitian Sari dan Karnadi (2019), berdasarkan hasil analisis dengan uji $t$ didapatkan sebesar 0,647. Hal ini berarti terdapat hubungan yang signifikan antara lingkungan kerja fisik terhadap loyalitas karyawan di tempat kerja dan pada penelitian ini lingkungan kerja non fisik lebih berpengaruh terhadap loyalitas karyawan dengan nilai koefisien regresi sebesar 0,405. Pada penelitian Rarindo, dkk (2019) berdasarkan hasil analisis diketahui bahwa untuk kategori efektifitas tata warna tempat kerja terhadap prestasi $\mathrm{K} 3$ pada pabrik semen kupang dikategorikan cukup baik. Hal tersebut dapat diketahui bahwa berdasarkan frekuensi terbesar 19 responden atau $63,33 \%$ yang berarti sebagian karyawan memiliki prestasi K3 cukup baik dengan dipengaruhi tata warna tempat kerja yang cukup baik. Sedangkan untuk efektifitas dekorasi tempat kerja terhadap K3, pada penelitian Rarindo,dkk (2019) kategori ini dikategorikan cukup baik. Hal tesebut dapat diketahui bahwa berdasarkan frekuensi terbesar 22 responden atau 73,33 \% yang berarti pada karyawan sebagian memiliki prestasi K3 cukup baik dengan dipengaruhi dekorasi tempat kerja yang memiliki kriteria cukup baik di pabrik semen kupang.

Pada penelitian Raodhah dan Gemely (2014) hasil uji statistik dengan chi square menghasilkan nilai $p=1,532 \quad(p>0,05) . \quad$ Sehingga memiliki nilai negatif yang berarti bahwa pengawasan perusahaan tidak memiliki hubungan dengan penggunaan APD pada karyawan. Pada kebijakan K3 mengenai penggunaan APD secara lengkap didapatkan hasil $p=0,00$ yang berarti terdapat hubungan antara kebijakan yang telah dibuat perusahaan dengan penggunaan APD secara lengkap.

\section{PEMBAHASAN \\ Karakteristik Responden}

Faktor umur mempunyai hubungan langsung dengan logika berpikir dan pengetahuan seseorang. Semakin matang usia seseorang, biasanya cenderung bertambah pengetahuan dan tingkat kecerdasannya. Menurut Kozier (2004), umur merupakan faktor yang dapat mempengaruhi persepsi seseorang. Umur dapat mempengaruhi daya tangkap dan pola pikir seseorang. Semakin bertambah usia, maka semakin berkembang pula daya tangkap dan pola pikirnya. Sebagian besar responden yang memiliki persepsi kurang baik terhadap penerapan SMK3 berada pada usia >40 tahun. Hal ini dapat menunjukkan bahwa ada kaitan antara umur dan persepsi seseorang. Di atas umur 40 tahun, 
tubuh mulai kehilangan kemampuan untuk terus-menerus memperbaharui selubung mielin, yaitu salah satu bagian yang penting dari sel saraf otak, sehinga menyebabkan berbagai gejala kognitif yang dikaitkan dengan penuaan (Ikhwan, 2004). Hal ini sesuai dengan yang dikemukakan oleh Lechman dalam Junita bahwa umur merupakan salah satu faktor yang memengaruhi produktivitas dan perilaku keselamatan kerja seseorang.

Hasil analisis pada penelitian Isa, dkk (2018) berbeda dengan teori dimana pada penelitian ini beberapa pekerja lama memiliki perilaku keselamatan yang kurang. Pekerja dengan masa kerja yang lama cenderung merasa sangat kenal dan paham terhadap tugas yang diberikan sehingga kewaspadaan mereka terhadap K3 berkurang dan secara tidak sadar berperilaku kurang aman. Namun pada penelitian yang lain masa kerja dipercaya dapat mempengaruhi iklim keselamatan. Hal ini karena lamanya seseorang bekerja dan pengalaman kerja yang dilaluinya dipercaya dapat memperbaiki meningkatkan efisiensi dan mempengaruhi sikap terhadap pekerjaan dan terutama terhadap keselamatan di tempat kerja (Muslima, 2017). Penelitian ini sejalan dengan penelitian Ravianto (1990) yang menyimpulkan bahwa karyawan/ tenaga kerja yang mempunyai masa kerja yang lama akan lebih terampil dan berpengalaman dalam mengerjakan pekerjaaannya sehingga hasilnya akan lebih baik.

Hasil uji statistik pada penelitian Almani, dkk (2014) yang menunjukan bahwa tidak ada hubungan antara tingkat pendidikan dengan persepsi penerapan SMK3 dikarenakan data yang diperoleh sangat tidak bervariasi. Pada penelitian ini kategori tingkat pendidikan rendah hanya 2 responden dan yang lainnya termasuk dalam kategori tingkat pendidikan tinggi. Hal ini disebabkan pada saat penerimaan karyawan, belum dikenakan sistem yang ada seperti sekarang. Hal ini tidak sesuai dengan teori maupun hasil penelitian sebelumnya yang menyatakan bahwa pendidikan memengaruhi proses belajar, makin tinggi pendidikan seseorang makin mudah orang tersebut menerima informasi. Dengan pendidikan tinggi, maka orang akan cenderung untuk mendapatkan informasi dari orang lain maupun dari media massa (Syartini, 2010). Hasil penelitian Ishak menyatakan bahwa tingkat pendidikan akan berpengaruh kepada daya intelegensi, tingkat pengetahuan, pola pikir, wawasan dan persepsi dalam rnengenal dan menganalisa berbagai persoalan berkaitan dengan Keselarnatan dan Kesehatan Kerja (K3) (Ishak, 2003).

\section{Safety Behavior}

Pengetahuan yang dimaksud dan dinilai dalam penelitian ini adalah pemahaman atau pengetahuan tentang SMK3 meliputi pengertian SMK3, tujuan, manfaat, dampak yang mungkin terjadi apabila tidak diterapkannya, serta bentuk-bentuk penerapan SMK3, peran serta karyawan dalam penerapan SMK3, komitmen perusahaan dalam penerapan SMK3, pemanfaatan APD, kondisi alat pemadam api, manfaat pemasangan rambu-rambu K3. Hal ini memang menunjukkan bahwa tidak terdapat hubungan antara pengetahuan rambu-rambu keselamatan (safety sign) dengan pencapain target pengisian semen pada bagian packer pada PT. Semen Bosowa Maros. Hal ini dikarenakan terdapat responden yang tidak 
mencapai target pengisian semen, padahal mereka telah memenuhi syarat pengetahuan $\mathrm{K} 3$ yang baik mengenai rambu-rambu keselamatan dan kesehatan kerja. Pendapat ini juga dikemukakan oleh Ramsey (1978 dalam Wibowo, 2010: 87) bahwa pengetahuan merupakan faktor yang sangat penting untuk terbentuknya perilaku seseorang, bila pekerja mempunyai pengetahuan yang kurang terhadap potensi ataupun sumber bahaya yang ada di lingkungan kerjanya, maka individu tersebut akan cenderung membuat keputusan yang salah, dalam hal penggunaan APD. Menurut Ishak (2003), apabila pengetahuan dan keterampilan tentang $\mathrm{K} 3$ tinggi dapat membangun persepsi karyawan terhadap penerapan $\mathrm{K} 3$ menjadi lebih baik.

Pelatihan K3 yang dimaksud adalah pelatihan yang pernah diikuti oleh karyawan selama bekerja di perusahaan. Pelatihan K3 digunakan untuk melatih pengetahuan dan keterampilan tertentu, keterampilan menggunakan peralatan dan mesin, atau keterampilan manajerial, yang berlangsung dalam waktu yang relatif singkat dan dalam jangka waktu pendek baik untuk tenaga kerja manajerial maupun untuk tenaga kerja bukan manajer. Biasanya perusahaan mempunyai pelatihan khusus diperuntukkan untuk tenaga kerja baru yang tidak melatih suatu keterampilan, melainkan diberikan pengetahuan tentang perusahaannya eperti, visi dan misi perusahaan, prosedur kerja, kebijakan, peraturan-peraturan, tentang pekerjaannya, dan lain-lain. Program latihan ini bertujuan agar para tenaga kerja dalam waktu singkat dapat mengenali dan menyesuaikan diri pada perusahaan dengan budaya perusahaannya
Pada teori Ravianto (1990) dalam penelitian Almani menyebutkan persepsi biasa digunakan seseorang untuk memandang ataupun menilai suatu objek. Persepsi seseorang terhadap suatu objek akan dipengaruhi sejauh mana pemahamannya terhadap objek. Persepsi seseorang sangat dipengaruhi oleh tingkat pengetahuan yang dimilikinya. Semakin tinggi tingkat pengetahuan seseorang maka semakin baik dalam mempersepsikan sesuatu. Persepsi antara tenaga kerja dengan tenaga kerja lain akan berbeda meskipun tingkat pendidikannya sama. Dalam dibidang K3 sendiri persepsi tenaga kerja yang baik akan berdampak pada pelaksanaan SMK3 yang baik pula. Persepsi tenaga kerja yang baik tentunya berpengaruh pada cara tenaga kerja berpikir, bersikap dan bertindak dalam pelaksanaan $\mathrm{K} 3$. Jika persepsi tenaga kerja terhadap penerapan SMK3 sudah baik maka akan menimbulkan sikap dan tindakan yang positif yang dapat mendukung terlaksananya penerapan SMK3 secara optimal (Almani, dkk., 2014).

Penelitian Nasrullah (2014) mengatakan adanya hubungan antara safety talk dengan pengetahuan safe bahavior, yang berarti bahwa tenaga kerja yang mendapatkan safety talk dengan baik kemungkinan akan mempunyai pengetahuan safe behavior yang baik. Safety talk merupakan pembacaan pesan-pesan singkat $\mathrm{K} 3$ yang dilaksanakan pada setiap hari sebelum para pekerja memulai pekerjaannya. Tujuan diadakannya program safety talk ini adalah agar para pekerja termotivasi dalam bekerja dan lebih berhati-hati dalam melakukan pekerjaannya. Safety talk dilakukan antara 5 sampai 15 menit dengan tidak menggantikan 
pelatihan formal, dengan safety talk diharapkan pekerja dapat mengetahui tentang kesehatan dan persyaratan keselamatan untuk peralatan, bahan, dan prosedur yang mereka gunakan setiap hari untuk pekerjaan tertentu (Gumelar dan Ardyanto, 2018). Hal ini sejalan dengan pendapat Tarwaka (2015) safety talk termasuk upaya pengendalian risiko yang ada dalam pengendalian administrasi. Menurut pernyataan Keller (2010) yang menyatakan bahwa safety talk tidak memerlukan waktu yang lama. Justru safety talk yang baik adalah safety talk yang singkat dan jelas.

\section{Budaya Keselamatan}

Pemimpin adalah orang yang dapat mempengaruhi perilaku orang lain untuk mencapai sebuah tujuan (Mulyono, 2013), gaya kepemimpinan dapat dirasakan dan dapat dinikmati hasilnya secara langsung dalam jangka pendek sehingga perubahan terhadap kepemimpinan akan berdampak secara nyata pada sebuah organisasi. Dikutip dari laporan International Association of Oil and Gas ProducersOGP (2013), tujuan utama dari kepemimpinan harus menginplementasikan sebuah sistem yang berjalan dengan memastikan penempatan dan penggunaan peralatan secara benar dalam pengoperasian dan pemeliharaannya. Pada penelitian Marzuki (2018) di Industri Migas dijelaskan sebuah kegiatan operasional, akan menghasilkan potensi bahaya terhadap orang dan lingkungan, oleh karena itu menjadi penting bahwa, manajemen berkomitmen pada praktik safety, kinerja operasional, dan aset integritas peralatan penting dengan baik, untuk mencegah terjadinya kecelakaan kerja. Selain itu menurut Gunawan, dkk, (2016) juga menyatakan bahwa perusahaan terbaik membutuhkan pemimpin yang tidak hanya mengejar laba jangka pendek tanpa mengelola manajemen operasi yang baik.

Pada penelitian Mulyono (2013) bahwa budaya K3 berpengaruh signifikan terhadap kepuasan kerja di Divisi operasi Tambang emas di PT Newmont Nusa Tenggara. Hal ini juga sesuai dengan penelitian Anna (2013) pada perusahaan tambang batubara di Polandia, bahwa budaya K3 yang ada jauh dari model ideal dari budaya K3 itu sendiri, dimana dalam manajemen keselamatan kerja peran sistem dan prosedur manajemen formal sangat dominan. Bentuk ideal pada budaya organisasi merupakan hasil dari kebiasankebiasaan yang mempengaruhi seseorang dalam organisasi tersebut dimana akan membentuk suatu persepsi keseluruhan mengenai organisasi yang berdasarkan pada faktor-faktor seperti toleransi risiko bahaya dan kecelakaan kerja, tekanan pada tim, dukungan rekan kerja, persepsi keseluruhan mengenai iklim keselamatan kerja. Hal ini akan menjadi budaya atau kepribadian organisasi yang seharusnya mampu mendukung dan mempengaruhi kinerja karyawan (Brahmasari dan Agus, 2008). Hal ini dapat dipahami bahwa budaya K3 adalah bagian dari budaya organisasi.

Pada teori motivasi dari Abraham Maslow dalam penelitian Marzuki (2018), menyatakan bahwa manusia ditempat kerjanya dimotivasi oleh suatu keinginan untuk memuaskan sejumlah kebutuhan yang ada pada seseorang, hirarki kebutuhan yang paling dasar sampai kebutuhan yang kompleks atau paling tinggi tingkatannya. Priansa (2016), menyatakan bahwa kepuasan kerja yang tinggi akan mendorong terwujudnya tujuan organisasi secara 
efektif, karena kepuasan kerja mencerminkan perasaan seorang terhadap pekerjaannya. Hal ini nampak pada sikap positif/negatif karyawan terhadap pekerjaan dan segala sesuatu yang dihadapi di lingkungan kerjanya. Hal ini juga didukung oleh penelitian Mulyono (2013) di PT Newmont Nusa Tenggara, dan penelitian Brahmasari dan Agus (2008), bahwa kepuasan kerja berpengaruh terhadap kinerja karyawan dan persepsi karyawan terhadap K3.

Lingkungan kerja yang baik adalah sebagai motivasi bagi karyawan sehingga mereka merasa nyaman dalam melakukan pekerjaaannya. Lebih bersemangat dan pada akhirnya dapat bekerja secara optimal, sehingga tidak dapat dipungkiri bahwa lingkungan kerja dalam suatu perusahaan mendapatkan perhatian yang lebih jauh dibandingkan pada waktu-waktu terdahulu. Lingkungan dan kondisi kerja yang tidak sehat merupakan beban tambahan kerja bagi karyawan atau tenaga kerja. Sebaliknya, lingkungan yang higienis tidak menjadi beban tambahan melainkan dapat meningkatkan gairah dan motivasi kerja (Soekidjo N, 2007: 205). Menurut Iswandi dalam penelitian Rarindo, dkk (2019) adanya dekorasi berdasarkan analisis potensi bahaya terkait dengan area tempat kerja, menunjukkan bahwa di tempat kerja memiliki potensi yang bervariasi namun juga memiliki jenis potensi bahaya yang sama. Dimana penerapan SMK3 terkait dengan dekorasi tempat kerja pada tingkat perusahaan yaitu berdampak positif, yang dapat mengurangi risiko bahaya di tempat kerja dan tentunya meningkatkan produktivitas kerja. Dalam kaitan dengan dekorasi tempat, tentunya dapat mempengaruhi prestasi keselamatan dan kesehatan kerja (K3).

Menurut Kelman (1958 dalam Wibowo, 2010 34) bahwa perubahan perilaku individu dimulai dengan tahap kepatuhan, identifikasi, kemudian baru menjadi internalisasi. Mula-mula individu mematuhi tanpa kerelaan melakukan tindakan tersebut dan seringkali karena ingin menghindari hukuman ataupun sanksi, maka biasanya perubahan yang terjadi pada tahap ini sifatnya sementara, artinya bahwa tindakan dilakukan selama masih ada pengawasan. Namun pada saat pengawas mengendur perilaku itu pun ditinggalkan lagi. Sedangkan kebijakan K3 adalah suatu pernyataan tertulis yang ditandatangani oleh perusahaan dan atau pengurus yang memuat keseluruhan K3. Kebijakan K3 dibuat melalui proses konsultasi antar pengurus dan wakil tenaga kerja yang kemudian harus dijelaskan dan disebarluaskan kepada semua tenaga kerja yang bersifat dinamik dan selalu ditinjau ulang dalam rangka peningkatan kinerja K3 (Permenaker/05/Men/1996).

Kebijakan K3 pada perusahaan merupakan perwujudan dari komitmen pimpinan yang memuat visi dan tujuan organisasi, dan tekad untuk melaksanakan K3, kerangka dan program kerja. Kebijakan dan peraturan $\mathrm{K} 3$ sangat penting dan menjadi landasan utama yang mampu menggerakkan semua partikel yang ada dalam organisasi sehingga program $\mathrm{K} 3$ yang diinginkan dapat berhasil dengan baik (Ramli, 2010:71). Berikut rekapitulasi hasil analisis faktor yang mempengaruhi manajemen dan iklim keselamatan di tempat kerja pada Industri Semen di Indonesia yang dapat dilihat pada tabel 1 . 


\section{KESIMPULAN}

Berdasarkan hasil penelitian studi literatur ini dilakukan dengan mengidentifikasi dan menganalisis dari 10 literatur utama yang bertujuan untuk melihat seberapa besar faktor pengaruh terhadap manajemen dan iklim keselamatan kerja di industri semen Indonesia. Setelah dianalisis terdapat beberapa faktor yang paling berpengaruh dalam manajemen dan iklim keselamatan kerja adalah faktor umur, masa kerja, sikap dan persepsi terhadap penerapan k3, pengetahuan keselamatan dan kesehatan kerja (K3), safety talk, gaya kepemimpinan transformasional, budaya organisasi, motivasi ekstrinsik, lingkungan kerja fisik di tempat kerja dan kebijakan k3 pada perusahaan.

\section{SARAN}

Berdasarkan hasil penelitian adapun saran yang baiknya dilakukan untuk makin meningkatkan kualitas iklim keselamatan kerja pada perusahaan semen di Indonesia yaitu: Disarankan kepada pihak perusahaan agar pekerja yang berumur tua $>45$ tahun tidak lagi dipekerjakan di bagian lapangan atau berkaitan dengan mesin cukup diruang kontrol, pekerja yang memiliki masa kerja terbilang baru harus selalu diperhatikan agar kecelakaan kerja akibat perilaku tidak aman dapat terkendali begitupun yang memiliki masa kerja lama atau sebaiknya dilakukan rotasi pekerjaan, diharapkan Divisi SHE (Safety Health and Environment) mengadakan pelatihan-pelatihan SMK3 yang sesuai dengan peran dan tanggung jawab tenaga kerja secara kontiniu untuk industri sejenis tentang pentingnya potensi bahaya yang mungkin terjadi di tempat kerja serta fungsi penggunaan APD saat bekerja dan memberikan kesempatan kepada karyawan untuk mengikuti pelatihan SMK3, pengetahuan yang baik tentang APD sebaiknya diiringi dengan pemberian safety talk sebelum bekerja agar pekerja dapat melakukan pekerjaan dengan tidak melupakan prosedur keselamatan kerja khususnya tentang penggunaan APD, kebijakan tentang penggunaan APD sebaiknya dipertegas melalui pemberian sanksi terhadap karyawan yang sering kali mendapat teguran khususnya penggunaan APD saat bekerja, memberikan pengarahan yang baik kepada karyawan, menjamin keamanan kerja bagi karyawan, dan membangun lingkungan kerja yang nyaman dengan fasilitas yang memadai bagi karyawan dan memberikan penghargaan kepada tenaga kerja yang patuh terhadap penggunaan APD dengan cara menempelkan nama tenaga kerja teladan dalam bentuk poster dan memberikan hadiah sesuai kemampuan perusahaan untuk memberikan rasa bangga terhadap tenaga kerja tersebut.

\section{DAFTAR PUSTAKA}

Almani, H., Wahyu, A., Rahim R. (2014). Persepsi Karyawan Terhadap Penerapan Sistem Manajemen Keselamatan Dan Kesehatan Kerja Di PT. Semen Tonasa. JURNAL MKMI, 10, 43-50. http://journal.unhas.ac.id/index.php/ mkmi/article/view/479

Ameko, F.N., (2015). Assessment of Safety Climate at La General Hospital.

Anna R., Joanna S. (2013) Safety Culture model and its Dimentions on the example of the coal mines in Poland. Management knowledge and learning. 19-21 June 2013. Zadar Croatia

Azrina, A. (2019). Evaluasi Iklim Keselamatan Kerja Dengan Menggunakan Metode Nosacq-50 di Pt. Permata Hijau Palm Oleo (phpo) KIM II MABAR. Skripsi. Program 
Studi Teknik Industri Fakultas Teknik Universitas Medan Area Medan

Basri, A. A., Ibrahim, H. (2018). Hubungan Pelaksanaan Program Keselamatan Kerja Dengan Produktivitas Karyawan PT. Semen Bosowa Maros. Journal of Industrial Hygiene and Occupational Health. http://ejournal.unida.gontor.ac.id/ind ex.php/JIHOH

Bergh,M. (2011). Safety Climate - An evaluation of the safety climate at Akzo nobel Site Stenungsund. Chalmers University of Technology Guteberg, Sweden.

BPJS. (2019). Kliping Berita BPJS Ketenagakerjaan Melalui Media Cetak dan Online.

Brahmasari, Ida Ayu, Agus S. (2008). Pengaruh Motivasi Kerja, Kepemimpinan, dan Budaya Organisasi, terhadap Kepuasan Kerja serta dampaknya pada Kinerja Perusahaan,(Studi Kasus pada PT Pei Hai International WiraTama Indonesia), Jurnal Manajemen Dan Kewirausahaan, Vol.10, No. 2, September 2008: 124-135.

Choudry, R.M., Fang, D., Lingard, H. (2009). Measuring Safety Climate of a Construction Company. Journal of Construction Engineering and Management 135, 890-899. http://doi: 10.106/?ASCE?CO.19437862.0000063CE

Dinas Tenaga Kerja dan Transmigrasi Sumatera Barat. (2019). Kecelakaan Kerja Tahun 2019. Sumatera Barat.

Ferret, E., Phill, H. (2002). Introduction To Health And Safety at Work Fourth Edition . Leicester: NEBOSH.

Flin, R., Mearns, K., O'Connor, P., \& Bryden, R. (2000). Measuring safety climate: Identifying the common features. In Safety Science. https://doi.org/10.1016/S09257535(00)00012-6

Guldenmund. (2010). Understanding and Exploring Safety Culture. Uitgeverji BoxPress, Delfi.

Gumelar, F., Ardyanto, D. (2018). Hubungan Kepatuhan dan Pengetahuan Tentang APD Dengan Safety talk di Unit Maintenance Perusahaan Semen. JPH RECODE. http://e-
journal.unair.ac.id/JPHRECODE

Gunawan, FA., Fatma L., Audist S., Slamet S.(2016). Manajemen keselamatan Operasi Membangun Keunggulan Operasi dalam Industri Proses. Gramedia: Jakarta

Hartaningrum, P., Mualifatul, B., Natsir, H. (2017). Penilaian Safety Climate Pekerja Terhadap Status Karyawan Dan Tingkat Pendidikan. Proceeding 1st Conference on Safety Engineering and Its Application.

ILO. (2018). Global Employment Trends for Youth 2018. International Labour Office. https://doi.org/92-2-113360$\underline{5}$

Indonesia Nomer Per. 08/Men/ VII/2010 tentang Alat Pelindung Diri, Jakarta: Berita Negara Republik Indonesia tahun 2010 Nomer 330

Isa, N., Widajati, N., Notobroto, B. (2018). An Analysis of The Effect Of Individual Characteristics And Physical Workload On Safety Behavior Among Cement Industry Production Workers. International Journal of Public Health and Clinical Sciences. $\quad 5, \quad 2289-7577$. https://doi.org/10.32827/ijphcs.5.5.1 $\underline{56}$

Ishak MN. (2003). Persepsi Manajemen Terhadap Resiko Kecelakaan Kerja dan Manafaat K3 dan Hubungannya dengan Penerapan Program K3 di Perusahaan $X$ Lhoeksumawe Aceh Utara [Tesis]. Medan: Universitas Sumatera Utara

Keller, K. (2010). Electrical safety code manual. Diakses dari: http://books.google.co.id/books?id= RWGr21jytsC\&printsec $=$ frontcover\&hl $=$ id\&source $=$ gbs ge summary $r \& c a d$ $=0 \# \mathrm{v}=$ onepage $\& \mathrm{q} \& \mathrm{f}=$ false

Kines, Pete, Lappalainen, Journal, Mikkelsen, K.L., Olsen, E., Pousette, A., Tharaldsen, J., ... Törner, M. (2011). Nordic Safety Climate Questionnaire (NOSACQ-50): A new tool for diagnosing occupational safety climate. International Journal of Industrial Ergonomics. https://doi.org/10.1016/i.ergon.2011 .08 .004

Kozier, M., (2004). Fundamental of Nursing: Concept, Process, and Practic, 7 ed. Pearson Education Inc, 
New Jersey

Mulyono. (2013). Pengaruh Budaya K3 dan Gaya Kepemimpinan Terhadap Kepuasan Kerja dan Kinerja Kerja. Jurnal Ilmu Ekonomi dan Manajemen. 9,

Marzuki, H. (2018). Pengaruh Budaya Keselamatan Kerja, Kepimimpinan Dan Motivasi Terhadap Kepuasan Kerja Dan Kinerja Karyawan Pada Perusahaan Minyak Dan Gas Bumi " $X$ " Di Propinsi Kalimantan Timur. Bisma Jurnal Bisnis dan Manajemen, 12,51-56.

Muslima, A. (2017). Gambaran iklim keselamatan kerja (Safety Climate) di Unit Base Maintenance PT Garuda Maintenace Facility (GMF) Aeroasia. Skripsi. Program Studi Kesehatan Masyarakat Fakultas Kedokteran dan IImu Kesehatan UIN Syarif Hidayatullah Jakarta.

Neal, A., Griffin, M. A., Hart, P. M. (2000). The Impact of Organizational Climate on Safety Climate and Individual Behavior. The Journal of Melbourne, Australia. Safety Science, 34, 99-109.

Nursindya, P. M. (2014). Pengaruh Disiplin Kerja, Keselamatan Kerja, Kesehatan Kerja Dan Lingkungan Kerja Terhadap Kinerja Karyawan PT Cement Puger Jaya Raya Sentosa. Prodi Managemen Fakultas Ekonomi Universitas Muhammadiyah Jember

Pramudianto, E. B. (2019). Pengaruh Budaya Organisasi Dan Lingkungan Kerja Fisik Terhadap Kinerja Karyawan PT. Semen Indonesia (PERSERO) TBK. Jurnal Ilmu Manajemen,7,299-306.

https://jurnalmahasiswa.unesa.ac.id/ index.php/jim/article/view/25853

Priansa, DJ. (2016). Perencanaan dan Pengembangan SDM, CV. Alfabeta, Bandung

Raodhah, S., Gemely, D. (2014). FaktorFaktor Yang Berhubungan Dengan Penggunaan Alat Pelindung Diri Pada Karyawan Bagian Packer PT Semen Bosowa Maros Tahun 2014. Al-Sihah : Public Health Science Journal, 2, 437-449. http://journal.uinalauddin.ac.id/index.php/AlSihah/article/view/1967

Ramli, Soehatman. (2010). Sistem
Manajemen Keselamatan \& Kesehatan Kerja OHSAS 18001. Dian Rakyat: Jakarta.

Rarindo, H., Harijono, Asrial. (2019). Efektivitas tata warna dan dekorasi tempat kerja terhadap Keselamatan dan kesehatan kerja pekerja pabrik semen. Jurnal Ilmiah Teknologi FST Undana, 13, 15-21. https://ejurnal.undana.ac.id/jurnal t eknologi/article/view/1714

Ravianto, J. (1990). Produktivitas dan Tenaga Kerja Indonesia. Jakarta: Lembaga Sarana Informasi Usaha dan Produktivitas

Rizky, I.A. (2019). Analisis Iklim Keselamatan Kerja Dengan Metode Nordic Occupational Safety Climate Questionnaire (nosacq-50) di Bagian Produksi PT. P\&P Lembah Karet Kota Padang. Skripsi. Jurusan Teknik Lingkungan Fakultas TeknikUniversitas Andalas Padang

Sari, Karnadi (2019). Pengaruh Lingkungan Kerja Terhadap Loyalitas Karyawan Pada PT. Semen Baturaja (Persero) Site Baturaja. Jurnal Adminika, 5, 35-45. http://journal.poltekanika.ac.id/index .php/adm/article/view/67

Shiddiq, S., Wahyu A., Muis, M. (2014). Hubungan Persepsi K3 Karyawan Dengan Perilaku Tidak Aman Di Bagian Produksi Unit IV PT. Semen Tonasa. JURNAL MKMI, 10, 110-116. http://journal.unhas.ac.id/index.php/ mkmi/article/view/501

Siu, O.L., Phillips, D.R., Leung T.W. (2003). Age Differences in Safety Attitudes and Safety Performance in Hongkong Constructions Workers. Journal of Safety Research 34. 199205. doi: $10.1016 /$ S022-4375

Soekidjo, N. (2005). Metodologi Penelitian Kesehatan. Jakarta:Rineka Cipta

Sucipto, A. (2014). Efektivitas Konseling DM dalam Meningkatkan Kepatuhan dan Pengendalian Gula Darah pada Diabetes Melitus Tipe 2. IJNP (Indonesian Journal of Nursing Practices).

Sugiono, E., Rachmawati, W. (2019). Pengaruh gaya kepemimpinan transformasional, Budaya organisasi danmotivasi ekstrinsik Terhadap 
kinerja karyawan PT Semen Padang, Jakarta Selatan. Jurnal IImu Manajemen, 15, 57-69.

Syartini T. (2010). Penerapan SMK3 dalam Upaya Pencegahan Kecelakaan Kerja di PT. Indofood CBP Sukses Makmur Divisi Noodle Cabang Semarang [Skripsi]. Semarang: Universitas Sebelas Maret

Tarwaka. (2015). Ergonomi Industri Dasar-Dasar Pengetahuan Ergonomi Dan Aplikasi di Tempat Kerja. Surakarta: Harapan Press.

Vinodkumar, M. N. \& Bhasi, M. (2009). Safety Climate Factors and Its Relationship with Accidents and Personal Attributes in The Chemical Industry. Safety Science, 47, 659667.

Wibowo, Arianto.(2010). Faktor - Faktor Yang Berhubungan Dengan Perilaku Penggunaan Alat Pelindung Diri Di Areal Pertambangan Pt. Antam Tbk unit Bisnis Pertambangan Emas Pongkor kabupaten Bogor"(skripsi): Bogor

Zohar, Dov. (1980). Safety Climate in Industrial Organizations: Theoretical and applied implications. Journal of Applied Psychology. Vol 65 (1): 96102

-----------, 2013, Shaping Safety Culture through safety leadership, OGP Report: No.45, diakses : www.ogp.org.uk 